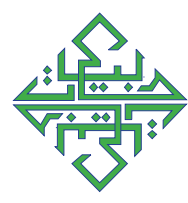

\title{
COLLOCATION OF ENGLISH, ARABIC, AND INDONESIAN COVID-19 TERMS
}

\author{
Darsita Suparno $^{1}$, Ulil Abshar ${ }^{2}$, Mulyadi ${ }^{3}$, Santje Iroth $^{4}$ \\ ${ }^{123}$ Universitas Islam Negeri Syarif Hidayatullah Jakarta, Indonesia \\ Jl. Ir. H. Juanda No. 95 Kota Tangerang Selatan, Banten, 15412, Indonesia \\ ${ }^{4}$ Universitas Negeri Manado, Indonesia \\ Jl. Kampus Unima, Kabupaten Minabasa, Sulawesi Utara, 95618, Indonesia \\ Corresponding E-mail: darsitasuparno@uinjkt.ac.id
}

\section{Abstract}

This paper studies language and translation of the term related to Covid-19. The background of this research is many new vocabularies related to Covid-19 is borrowing term. This study attempts to find answers to the following question: a) What kind of collocations are related to the term Covid-19 pandemic in English, Arabic, and Indonesian? b) How is the pattern of word order forming collocations with the term Covid-19 pandemic in English, Arabic, and Indonesian? This study addressed the emergence of new English, Arabic, Indonesian collocation related to Covid-19 using H. Men's collocation theory. This study used newspapers, namely Republika, BBC, al-Jazeera online that show Covid-19 as the standard procedure for collecting data. This study used corpus linguistic to analyze collocation, concordance, and syntax analysis, models. The Covid-19 domain has chosen because the Indonesian term in this domain uses a lot of loanwords. The source of the data was a basic-words and compound term. The investigation informed several aspects of findings, such as identifying the pattern of collocation, borrowing, and collocation term of coronavirus concept.

Keywords: pandemic, Covid-19 term, collocation, concordance

\section{Introduction}

Collocation is a linguistic phenomenon that occurs in all languages because various events surround the life of human beings, one of the examples of events of nature in the form of "Coronavirus Desease" (Covid-19) when it is is supposed to be the cause of the emergence of collocation vocabulary for example native speaker to say bydrocblorquine namely 'obat anti radang', as well as Indonesian people bydrocblorquine, and Arabs will say هيدروكلوروكين on clause انظر هيدروكلوروكين 'view hydrochlorquine' the element of language is dependent the context of the use of language, occur 
regularly. Another example is that native speaker said herd immunity, the Arabs say and Indonesian said kekebalan kelompok. Symptoms of language that shows the concepts as this newly emerged at the end of the year 2019, but the research of collocation has been carried out by experts.

A number of researches about collocation have been conducted. Zaabalawi and Anthony discuss collocation of English languages obtained from the novel, color, idiom used in learning languages as multi words combination using web, ${ }^{1}$ Ihalainen and Aleksi researched the use of collocation of English that appeared in the realm of politics in England by discourse analysis approach ${ }^{2}$. Furthermore, Izwaini examines the collocation of Arabic in the daily use of Arabic in the United Arab Emirates. Analyzing collocation using the approach of semantic prosody, ${ }^{3}$ Al-Thubaity and Baazeem studied collocation of Arabic language which is used in the text of news on various letter word, ${ }^{4}$ There are 11 languages of Arabic became the object of research, namely Algeria, Bahrain, Egypt, Iraq, Jordan, Kuwait, Morocco, Saudi Arabia, Sudan, Uni Arab Emirates, and Yemen. Text news that investigated is the use of language in the realm of policy, economic, social, sports, religion, culture, health, science and technology. Analysis collocation and term using analytical $\mathrm{X}^{2}$, the Dice coefficient (DICE), t-score, Z-score, and the weirdness software. ${ }^{5}$

Rahman did research collocation of Indonesian and English in pandemic of Covid-19, using approach to the analysis of discourse. Results of the study show the collocation associated disease much came from English ${ }^{6}$. While Aji researched collocation and hyponymy and hypernymy of Indonesian in authoritative advertising.

1 Rafe S. Zaabalawi and Anthony M. Gould, "English Collocations: A Novel Approach to Teaching the Language's Last Bastion", Elsevier Ltd 4, 2017, 21-24; See again Jahangeer Khan and Chengyu Liu, "The Impact of Colors on Human Memory in Learning English Collocations: Evidence from South Asian Tertiary ESL Students", Springer Open, Vol. 5, No. 17, 2020, 2; See again Elaheh Rafatbakhsh and Alireza Ahmadi, "A Thematic Corpus-Based Study of Idioms in the Corpus of Contemporary American English", Springer Open, Vol. 4, No. 11, 2019, 3; See again Eduardo de Gregorio-Godeoa and Silvia Molina, "Collocations and the Translation of News: An English_Spanish Electronic Dictionary of Multi-Word Combinations as a Translation Tool", Routledge, Taylor and Francis Group, Vol. 19, No. 2, 2011, 136; See again N Hizbullah, and Muchlis, "Projected Characteristics and Content of Arabic Corpus in Indonesia", 2018.

2 Pasi Ihalainen and Aleksi Sahala, Evolving Conceptualisations of Internationalism in the UK Parliament In M. Fridlund, M. Oiva, \& P. Paju (Eds.), Digital Histories: Emergent Approaches within the New Digital History, (Helsinki: Helsinki University Press, 2020), 199-202.

${ }^{3}$ Sattar Izwaini, "Patterns of Lexical Collocations in Arabic", 2015, 2-5.

4 Abdulmohsen Al-Thubaity and Ibtehal Baazeem, "A Collocation Extraction Tool and Two Language Resources for MSA”, Elsevier Ltd, 116, 2017, 25; See again Zainab Kadim Igaab and Hanan Abdulhasan1, "Collocation in English and Arabic: A Contrastive Study", Canadian Center of Science and Education, Vol. 8, No. 4, 2018, 90; See again Nur Hizbullah and Zakiyah Arifa, "Source-Based Arabic Language Learning: A Corpus Linguistic Approach”, Humanities \& Social Sciences Reviews, Vol. 8, No. 3, 2020, 941.

5 Al-Thubaity and Baazeem, "A Collocation Extraction Tool and Two Language Resources for MSA", 25-26; See again Claire Brierley and Hanem El-Farahaty, "An Interdisciplinary Corpus-Based Analysis of the Translation of كرامة (Karāma, 'Dignity') and Its Collocates in Arabic-English Constitutions", JoSTrans: the Journal of Specialised Translation, No. 32, 2019, 121.

6 Abd. Rahman, "Keberterimaan Istilah-Istilah Di Masa Pandemi Covid-19", Bidar, Vol. 10, No. 2, 2020, 80 . 
The analysis was done by using the semantic approach. Results of the study show the collocation and hyponymy and hypernymy of Indonesian in advertising can be used as an ingredient of learning Indonesian in the high school. ${ }^{7}$ In the summary, the results of research collocation have multiple uses, namely for the manufacture of a dictionary, learning a language, the acquisition of language, create a policy use of language for special purpose, computational linguistics.

Focused on the opinion of the experts, the linguistic corpus is understood as an illustration of the use of language is advanced from a society that is based on the examples were obtained from the use of language in reality. Therefore, based on a scale of cross-culture, in particular, the use of language pandemic Covid-19 paper is reviewing collocation and concurrency on word structure phrases of English, Arabic, and Indonesian. As far as literature searches by the author, the object of this research has never been studied by experts.

Departing from the explanation in the above can be known that the study of collocation in the realm of coronavirus in the English, Arabic and Indonesian based corpus using Leipzig corpora software has not been carried out the expert. To fill the gaps, the problem of research is formulated as follow: a) what collocation are related to the term Covid-19 pandemic in English, Arabic, and Indonesian? b) how is the collocation order pattern related to the term Covid-19 pandemic in English, Arabic, and Indonesian. The research is aimed to a) classify the form collocations associated with the term pandemic Covid-19 in English, Arabic, and Indonesian, b) describe the shape of concurrency associated with the term Covid-19 pandemic in English, Arabic, and Indonesian, c) find patterns order sequence of words forming the collocation associated with the term pandemic Covid-19 in English, Arabic and Indonesian.

The study is to discuss the linguistic corpus to observe collocation, cooccurrence and pattern layout sequence of words forming the collocation in English, Arabic, and Indonesian. Results of the research through comparative language, absorption vocabulary from one language to entire Indonesian can understand the terms are associated with a pandemic Covid-19 is so that people can protect themselves by way of changing the way of life clean to be spared from the threat of dangerous disease. The study is also expected able to provide theoretical approaches that are much better against the specificity and universality language, especially English, Arabic, which became the language of donor to Indonesian. Data collocation related to pandemic Covid-19 also can be used as a basis for the study of interlanguage. In addition, the research is expected to give a contribution not only in language pedagogy of both but also on the development of the current study on linguistic corpus, and studies across cultures associated with the reality of the language in society, especially in the field of health.

${ }^{7}$ Pandu Rizki Aji, "Kolokasi Dan Hiponim Sebagai Aspek Keutuhan Wacana Iklan Otomaotif Dalam Surat Kabar Suara Merdeka Periode Mei 2014 Dan Implikasinya Pada Pembelajaran Di SMA”, Thesis, Universitas Muhammadiyah Purwokerto, 2015, 12. 
Corpus linguistic appears in line with the development of the use of technology computer, ${ }^{8}$ Linguistic corpus is a method of searching the meaning of words, phrase to engage the text in a number of large and using assistance device computer to analyze the data. ${ }^{9}$ Corpus linguistic focused on the procedures or methods of analyzing language based software. ${ }^{10}$ Corpus linguistic is a study of the use of language in reality, the data observed may be the data of oral and written and analyzed by using the device corpus software then elaborated with the approach of linguistics, then described using the angle of specific view and purpose, one of the objects of study are collocation and co-occurrence. ${ }^{11}$ Studies on a variety of linguistic aspects such as speech, vocabulary (lexicon), sociolinguistics, pragmatic, and others have been using the corpus as accurate and representative database. ${ }^{12}$ Collocation is an abstraction of syntagmatic level. ${ }^{13}$ Collocation also can be defined as the co-occurrence of the words. Co-occurrence is a copula or node whose formation follows core word that is position can be located on the side right or left. In the short, collocation is a phenomenon which shows a word can be combined with the word the word certain in a context of limited anyway. ${ }^{14}$ Next, concordance is a list or sequence of several examples of a word, par or combination of a word that is in a context and sourced from the corpus text, ${ }^{15}$ In short, concordance contributes an actual example of how a word is used in the context.

\section{Method}

The corpus linguistic approach is used in this syntactic research. This linguistic study at the syntactic level was carried out to understand the collocations that emerged during the coronavirus outbreak in English, Arabic and Indonesian. Data was

${ }^{8}$ Ge Lan and Yachao Sun, "A Corpus-Based Investigation of Noun Phrase Complexity in the L2 Writings of a Firstyear Composition Course", Elsevier Ltd, Vol. 38, 2018, 14; See again Ibrahim Alasmri and Haidee Kruger, "Conjunctive Markers in Translation from English to Arabic: A CorpusBased Study”, Routledge, Taylor and Francis Group, Vol. 26, No. 5, 2018, 2.

9 T. McEnery and Hardie A, Corpus Linguistics: Method, Theory and Practice, (Cambridge: Cambridge University Press, 2012), 1.

10 A O'Keeffe, and M. McCarthy. The Routledge Handbook of Corpus Linguisfics, (London: Routledge, 2010), 195; See again McEnery and A Hardie, Corpus Linguistics: Method, Theory and Practice, (Cambridge: Cambridge University Press, 2011)

${ }^{11}$ Lan and Sun, "A Corpus-Based Investigation of Noun Phrase Complexity in the L2 Writings of a Firstyear Composition Course", Journal of English for Academic Purpose, Vol. 38, 2019, 24; See again Paschal Maher and Simon Milligan, "Teaching Master Thesis Writing to Engineers: Insights from Corpus and Genre Analysis of Introductions”, Elsevier Inc, Vol. 55, 2019, 42.

12 Faisal Hendra and Mujahidah Fharieza Rufaidah, "Compiling Vocabulary Lists For Corpusbased Arabic For Tourism Teaching”, Arabiyat, Vol. 8, No. 1, June 2021, 94.

13 A O'Keeffe, and M. McCarthy. The Routledge Handbook of Corpus Linguisfics, (London: Routledge, 2010), 122-123; See again Al-Thubaity and Baazeem, "A Collocation Extraction Tool and Two Language Resources for MSA”, Procedia Computer Science, Vol. 117, 2017, $23-24$.

${ }_{14}$ M Stubbs, Words and Phrases: Corpus Studies of Lexical Semantics, (London: Blackwell Publishing, 2002), 29-30; See again Dewi Puspita, "Etimologi Kosakata Melayu Nusantara Ranah Kekerabatan Kajian Semantik Historis", Thesis, (Universitas Indonesia, 2020), 78-79.

${ }^{15}$ McEnery and Hardie A, Corpus Linguistics: Method, Theory and Practice. 
collected using a qualitative method, namely the study of documents. ${ }^{16}$ The main characteristics in the corpus linguists enable researchers to examine the phrase structure collocation and concordance of aspects. The collocation analysis technique of the concordance line is applied from the technique. ${ }^{17}$ Qualitative description refers to the procedures for settling the problem by describing the state of the object of research based on the facts that appear. ${ }^{18}$ The source of qualitative research data is the appearance of spoken or written words. Qualitative data in the form expressed in a series of words that give meaning to term Covid-19 pandemic.

The author analyzes the syntactic structure, especially phrases containing collocations and co-occurrence, the data can provide linguistic aspects in the form of descriptions. The subject in this study is the term regarding the Covid-19 pandemic used by the wider community in various news. The object of this research is co occurrence collocation which is focused on terms that appear during the Covid-19 pandemic. The technique used in this study was the observation techniques and pen record the data. In this study, the documents used as data sources are divided into two parts. The first data source is the use of language in online print media that discusses the coronavirus pandemic which is the main object of this research. The second source of data referring to the first corpus is a dictionary of books, articles, printed and online mass media reports. To see the collocation and co-occurrence of the corpus in English, Arabic, and Indonesian, the Leipzig Corpora application was used. Leipzig Corpora is a collection of online corpus developed by the Institute of Computer Science.

\section{Result and Discussion}

The use of the word associated with the coronavirus began to be used as widely at the end of 2019. In corpus linguistics, words that appear on the side right or left of the word studied is called collocation. Collocation is a picture that remains between the word with another word that side in a sentence. ${ }^{19}$ The use collocation seen from the data shown in Table 1 below this:

Table 1. Collocation of Coronavirus Term in English, Arabic, and Indonesian

\begin{tabular}{|c|c|c|c|c|}
\hline & English & Arabic & Indonesian & Word class \\
\hline 1. & coronavirus & فيروس كورونا & virus-corona & noun \\
\hline 2 & vomit & أداة العدوى & muntah & noun \\
\hline 3 & blood plasma & بلازما الدّم & plasma darah & noun \\
\hline 4 & cluster & عنقود & kluster & noun \\
\hline 5 & gloves & قفازات & sarung tangan & noun \\
\hline 6 & immunity & مَنَاعَةُّ & imunitas & noun \\
\hline
\end{tabular}

${ }^{16} \mathrm{~J}$. W. Creswell, Research Design Qualitative Quantiative and Mixed Methods Approaches Third Edition, Third Edition. (California: SAGE Publication, Inc., 2009), 145-150.

${ }_{17}$ McEnery and Hardie A, Corpus Linguistics: Method, Theory and Practice, 126.

${ }^{18}$ Sugiyono, Metode Penelitian Kuantitatif, Kualitatif Dan RひDD. (Bandung: Alfabeta, 2014), 205.

${ }^{19}$ H. Men, Vocabulary Increase and Collocation Learning, (Shanghai: Springer, 2018), 4, 36. 


\section{Arabiyât Jurnal Pendidikan Bahasa Arab dan Kebahasaaraban, 8 (2), 2021}

\begin{tabular}{|c|c|c|c|c|}
\hline 7 & infectiouse & عَذْوانيُ & menular & noun \\
\hline 8 & diagnostic & تشخيص & diagnosis & noun \\
\hline 9 & endemic & متوطّن & endemic & adjective \\
\hline 10 & epidemic & وباءs & epidemic & adjective \\
\hline
\end{tabular}

This study has resulted in two findings namely: 1) collocation based on its types, and 2) collocation based on the meaning. Collocation is identified as a relation of lexical meaning between an element and another element. In this case, similarities association of their few words in the same area in a sentence explain that collocation is the association remained word with another word in a sentence. The concept of sanding kata is associate particular in using choice words that tend to be used in side by side. ${ }^{20}$

\section{Lexical Collocation Related to Coronavirus in English}

Lexical collocation reference to shape a phrase that consists of a combination of a noun, adjective, verb, and adverb. Lexical meaning is the meaning of the word that is actually following the reference as a result of observation senses and apart from the element of grammatical, or can also be said as the meaning of the original word ${ }^{21}$, 22. The lexical is straightforward meaning. The meaning of the word is not influenced by other form. Coronavirus in English, the form of the collocation can be seen in the form of a graph of Leipzig corpus in graph 1 as follows: collocation word epidemic in English.

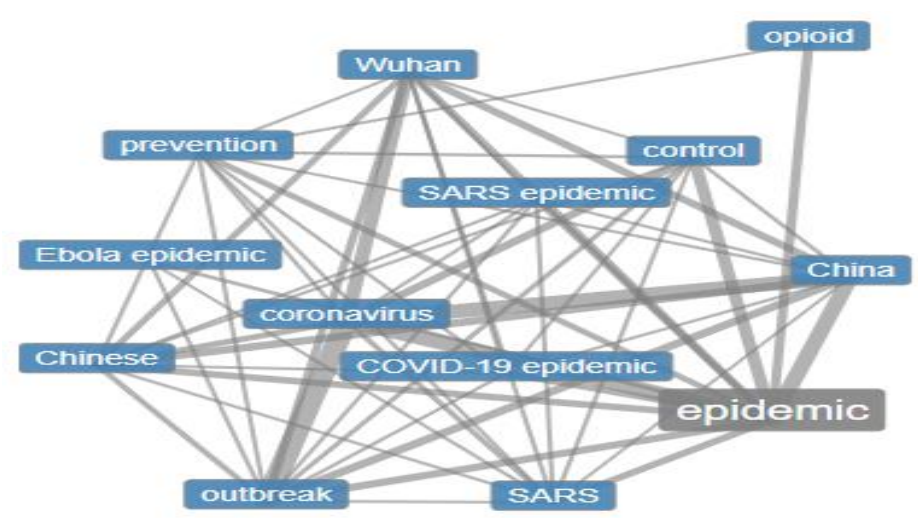

Source: https:// corpora.uni-leipzig.de/

Table 2. Collocation lexical term is associated coronavirus in English

\begin{tabular}{llll}
\hline No & Example & \multicolumn{2}{c}{ Category } \\
\hline & Lexical collocation in English & Word class & Word class \\
\hline 1 & [Wuhan epidemic] & noun & Adjective
\end{tabular}
MSA," 24.

${ }^{20}$ Al-Thubaity and Baazeem, "A Collocation Extraction Tool and Two Language Resources for

21 Violeta Seretan, "Bridging Collocational and Syntactic Analysis in Lexical Collocation Analysis" (Spain: Springer, 2018), 23-27, https://doi.org/10.1007/978-3-319-92582-0_2.

22 Pascual Cantos-Gómez and Moisés Almela-Sánchez, Lexical Collocation Analysis Advances and Applications (Spain: Springer, 2018), 23, https://doi.org/10.1007/978-3-319-92582-0. 
Arabiyât Jurnal Pendidikan Bahasa Arab dan Kebahasaaraban, 8 (2), 2021

\begin{tabular}{llll}
\hline 2 & [epidemic prevention] & adjective & Noun \\
\hline 3 & [epidemic control] & adjective & Verb \\
\hline
\end{tabular}

In the corpus of Leipzig, collocation is divided based on the location of coocurenses (kemunculan kata yang menyertainya). There are two coocurences, left neighbor coocurences and right coocurences. Coocurences for the epidemic listed in Table 3. (Kookurensi Kemunculan Kata Penyerta)

Table 3. (Kookurensi Kemunculan Kata Penyerta)

\begin{tabular}{ccc}
\hline Left & word & Right \\
\hline Coronavirus & epidemic & \\
\hline & epidemic & prevention \\
\hline Global & epidemic & \\
\hline
\end{tabular}

The data listed in table 3 shows that collocation of "epidemic" very much found in the text that contains information about coronavirus disease into the issue that comes across since the 2019 until now. Figure 1 the emergence of vocabulary that follow the term coronavirus as many as 16.597, appears on the next left, for sample this research are 144 was taken as a random with the reason each Data has a pattern structure lexical who built based the word class. Figure 1 the emergence of words that only can appear in the next left.

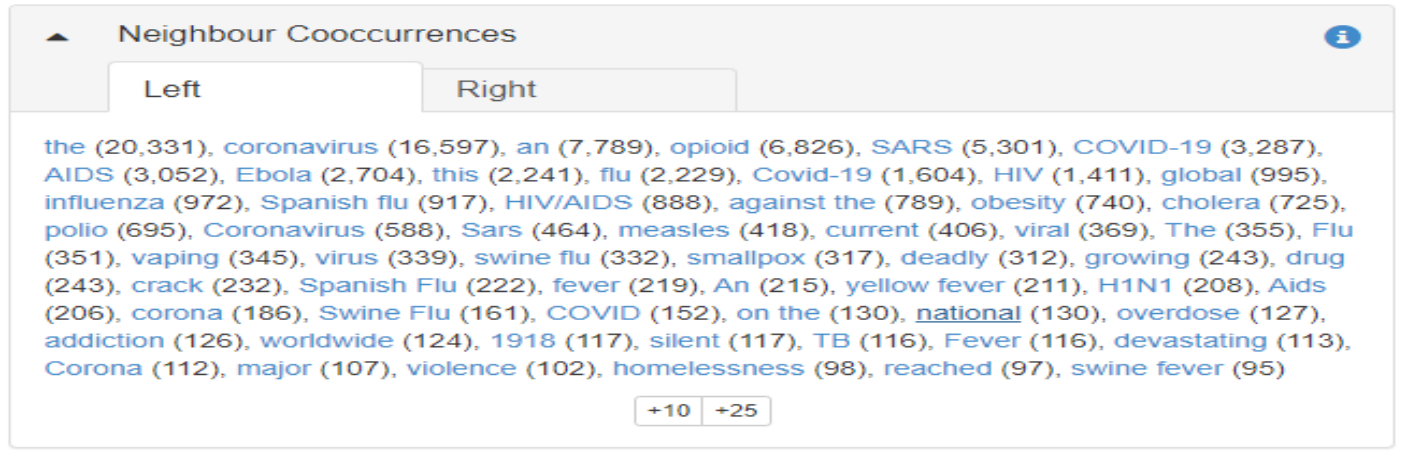

Source: https://corpora.uni-leipzig.de/

Figure 2 The emergence of vocabulary that follow the term coronavirus in the side right
- Neighbour Cooccurrences
Left
Right

prevention $(2,990)$, is $(2,086)$, in $(1,837)$, has $(1,562)$, curve $(1,297)$, under control $(884)$, control (866), situation (740), began (691), proportions (442), continues (365), could (357), was (312), under (298), that (293), will (264), of (237), spread (237), started (216), wave (208), diseases (205), preparedness (198), response (190), levels (181), spreads (169), and (166), disease (159), curves (155), may (142), that is (137), broke (136), peaked (123), worsens (119), hit (114), prevention," (113), sweeping (110), could be (104), peak (102), originated (93), spreading (93), struck (90), outbreak (89), peaks (88), rages (81), waves (81), grows (81), raged (79), subsides (74), swept (71), growth (67), jumped (64), erupted (61), affecting (60), modeller (57), wanes (55), ravaging (54), or (53), requires (53), triangle (53), raging (51)

Source: https://corpora.uni-leipzig.de/ 
Figure 1 The emergence of vocabulary that follows the term coronavirus in the next right as many as 2.990 , which was used as a sample in this research is as much as 130 was taken as a random with the reason each Data will have a pattern structure lexical were built by the word class. So, lexical collocation that much of this has become a factor essential to trigger the increase of knowledge (cognitive) for all the people to introspect themselves to this issue. This research is finding the pattern which often appears in the form phrases nouns and phrases adjective.

\title{
Grammatical collocation Associated Coronavirus in English
}

To understand the use of collocation in English discovered 9.010, the term is collocation. The collocation related to that term can be seen in Figure 3

\section{- Words occurring in the Same Sentence}

\begin{abstract}
coronavirus $(9,010)$, COVID-19 epidemic $(8,824)$, the $(7,869)$, SARS epidemic $(6,253)$, China $(6,086)$, opioid $(4,810)$, SARS $(4,165)$, AIDS epidemic $(3,360)$, of $(3,187)$, Ebola epidemic $(3,154)$, control $(2,999)$, Wuhan $(2,758)$, prevention $(2,506)$, outbreak $(2,421)$, Chinese $(2,240)$, Ebola $(2,233)$, AIDS $(2,225)$, spread $(2,195)$, an $(1,990)$, HIV epidemic $(1,989)$, health $(1,931)$, measures $(1,795)$, in $(1,755)$, global $(1,711)$, peak $(1,636)$, virus $(1,616)$, China's $(1,543)$, flu $(1,535)$, disease $(1,450)$, cases $(1,435)$, Xi $(1,404)$, COVID-19 $(1,399), 2003(1,357)$, has $(1,349)$, Coronavirus epidemic $(1,326)$, countries $(1,274), 1918(1,272)$, response $(1,241)$, HIV $(1,233)$, Hubei $(1,220)$, toll $(1,132)$, contain $(1,106)$, under control $(1,099)$, deaths $(1,092)$, country $(1,089)$, WHO $(1,065)$, Spanish flu epidemic $(1,031)$, China's $(990)$, infected (988), influenza (973), death toll (960), epicenter (941), Health (927), infections (914), during (906), to (902), curve (887), Covid-19 (880), people (880), that (878)
\end{abstract}

Source: https:/ / corpora.uni-leipzig.de/

Table 4. Grammatical collocation in English

\begin{tabular}{lllllll}
\hline No & Example & \multicolumn{2}{c}{ Composition } \\
\hline \multicolumn{7}{l}{ Kolokasi gramatikal } \\
\hline 1 & [of the U.S. COVID-19 epidemic] & Prep & article & Noun & noun & adjective \\
\hline 2 & [As the COVID-19 epidemic] & Adverb & article & Noun & noun & adjective \\
\hline 3 & [Although the COVID-19 epidemic] & Conjunt & article & adjective & adjective & \\
\hline
\end{tabular}

A grammatical collocation is a phrase that consists of the word dominant (noun, adjective, and verb) and preposition/word function or form grammatical as verb infinitive and clause. ${ }^{23}$ Focused to the concept that research is finding some use collocation in a discourse that contains news about the coronavirus disease. The sentences were identified as collocation which has a structure syntax as follows:

${ }^{23}$ H. Men, Vocabulary Increase and Collocation Learning, 36. 


\section{Data 1 of the U.S. COVID-19 epidemic}

Data 1 unit language of the U.S. COVID-19 epidemic were identified as collocation which has a structure syntax as follows: preposition + determiner + Noun + Noun + Adjective. Collocation in data 1 of the U.S. COVID-19 epidemic consists of three words, namely cured (sembuh), from (dari) and coronavirus. Collocation type is found in the form of a phrase preposition that consists of a preposition and object of a preposition (object of the preposition). This phrasee functions as word description or adverbs in the text message about coronavirus. A prepositional phrase can be terminated by a noun, or clauses that function or role as the object of a preposition such. Based on the results of the analysis, it can be found that the coronavirus associated collocation has a pattern of structures that vary depending on the context and concepts are presented. Collocation patterns related terms coronavirus in English are 144 collocation structured phrase, 84 noun patterned Noun+ Adjective4, and the structure of the phrase adjective as much as 60 patterned Adjective + adjective; 2) A grammatical aspect was found in the form of verb phrase 1, noun 1, prepositional and adverbial phrase. Research is finding 132 data grammatical collocation with 68 collocation structure Adverb+Article+Noun+Adjective, 34 collocation structure Preposisi+Article+Noun+Adjective; 20 collocation structure Noun+Adjective+Noun; and 12 collocation structure possessive pronounce + Noun + Adjective. The pattern of co-occurrences associated coronavirus in English found. The pattern that often appears is the form of noun phrase and adjective phrase.

\section{Arabic Collocation}

Collocation or sanding kata that remains among words that side by side in a sentence. this research has resulted in two findings staple, namely 1) the category of collocation according to its kind, and 2) categories of collocation according to the meaning. The concept of collocation is used to analyze Arabic collocation data, to distinguish two concepts: morphological and syntactic analysis. Analysis of the morphology refers to the process that determines to particular all the analysis of morphology. In Arabic, word it might term of clitic word class like articles, preposition, conjunction, and pronouns. The syntactic aspect refers to the lexical and grammatical categories. Category by type consists of lexical collocation, namely Coronavirus related lexical collocation in Arabic

Lexical collocation refers to the form of a phrase consisting of a combination of a noun, adjective, verb, adverb. In this collocation, every word biting has lexical meaning. The lexical meaning is the meaning of the word that is in accordance with the reference as a result of observation senses and apart from the element of grammatical, or can also be said as the meaning of original a word. The lexical meaning is the meaning that is contained in the dictionary. ${ }^{24}$ Lexical meaning are

${ }^{24}$ Nick Riemer, Introducing Semantics, (Cambridge: Cambridge University Press, 2010), 21, 338. 
common or straightforward that is not influenced by the other form. ${ }^{25}$ Based on the data was found words that can be collocation with حظر word. The meaning of collocation of حظر is 'lockdown' in Arabic as shown in chart 2 at the bottom of this:

Graphic 2. Collocation of حظر Arabic

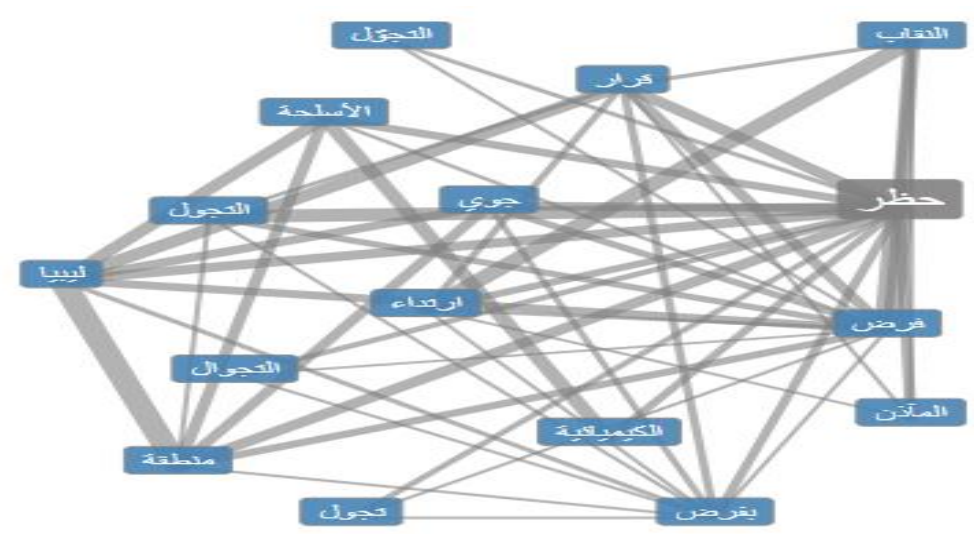

Source: https://corpora.uni-leipzig.de/

The word حظر is identified as a compound word. The word is constructed by nouns and nouns. It is also identified as a loan word from English. The collocation cab be seen in table 5 as follows, an example of the use of the word حظر 'lockdown' in sentence.

Figure 4 The use حظر in sentence

- Words occurring in the Same Sentence

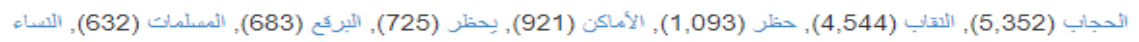

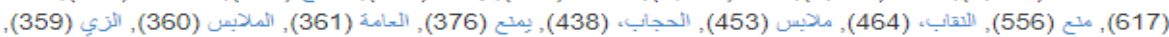

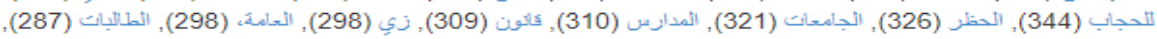

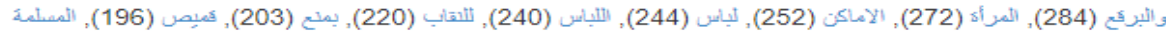

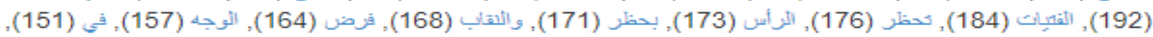

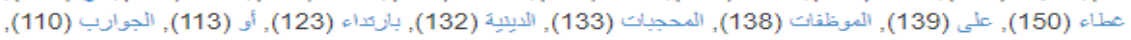

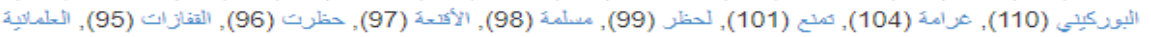

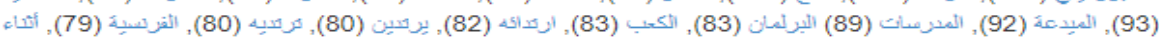

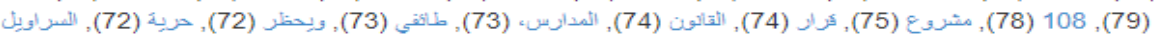

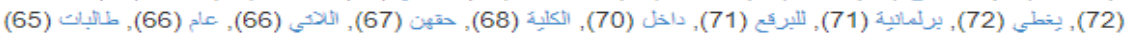

Source: https://corpora.uni-leipzig.de/

The word of حظر in Arabic associated with coronavirus is used as much as 4.544 sentences. The following is a sample of that sentence.

$$
\begin{aligned}
& \text { ا ب وقال أو سينوف البرلان في إطار حالة الطوارئ، فرض حظر للتجول في البلاد. }
\end{aligned}
$$

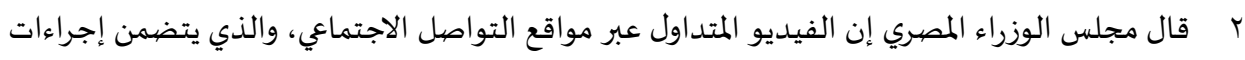

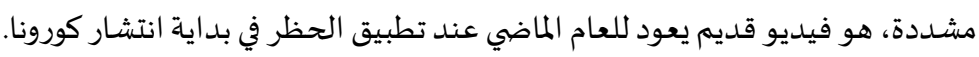

Source: https://www.epa.gov/lep/19-dyfwk-hyj-nth-tsrmml-ldf-myqtlw-fyzntl

Based of the example sentences are used as sample can be found that the collocations of Arabic in term aspects of lexical can be describe in table 5 as follows.

${ }^{25}$ George Yule, The Study of Language, (Cambridge: Cambridge University Press, 2013), 113. 
Table 5. Lexical collocation of Arabic

\begin{tabular}{|c|c|c|c|c|c|}
\hline No & Example & & rory & & \\
\hline & Collocation in Arabic & $\begin{array}{l}\text { Word } \\
\text { class }\end{array}$ & $\begin{array}{l}\text { Word } \\
\text { class }\end{array}$ & Word class & $\begin{array}{l}\text { Word } \\
\text { class }\end{array}$ \\
\hline 1 & قسوة فيروس كورونا & Noun & Noun & Noun & \\
\hline 2 & لقاح كورونا فيه & Noun & Noun & Preposition & Noun \\
\hline 3 & فيروس كورونا يشتت شمل & Noun & Noun & preposition & Verb \\
\hline
\end{tabular}

Based on the data from 112 sentences, three lexical collocation pattern were found, namely: i) 66 collocations with noun+noun+noou; ii) 36 collocations with noun+verb; iii) 20 collocation with noun_noun_preposition+verb. The appearance of the word on the left related to coronavirus can be seen in figure 5 below.

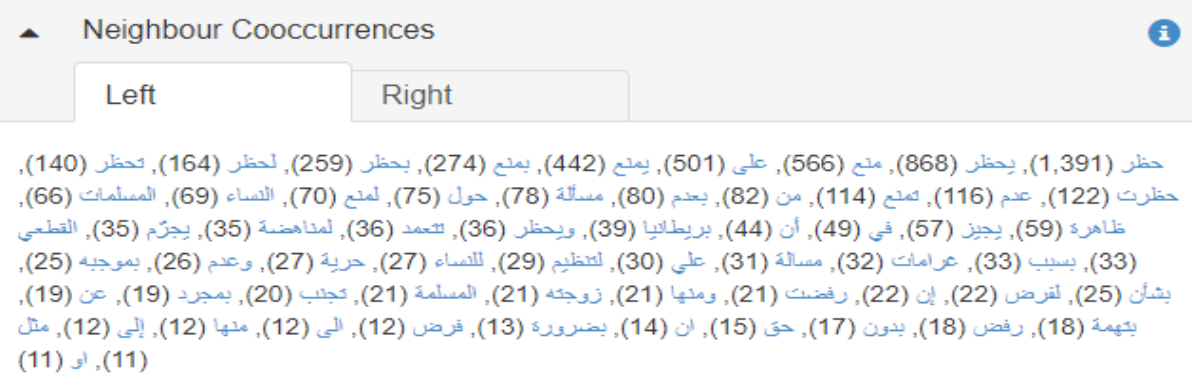

Figure 5 shows the word حظر may appear in the next left as many as 1.391 times.

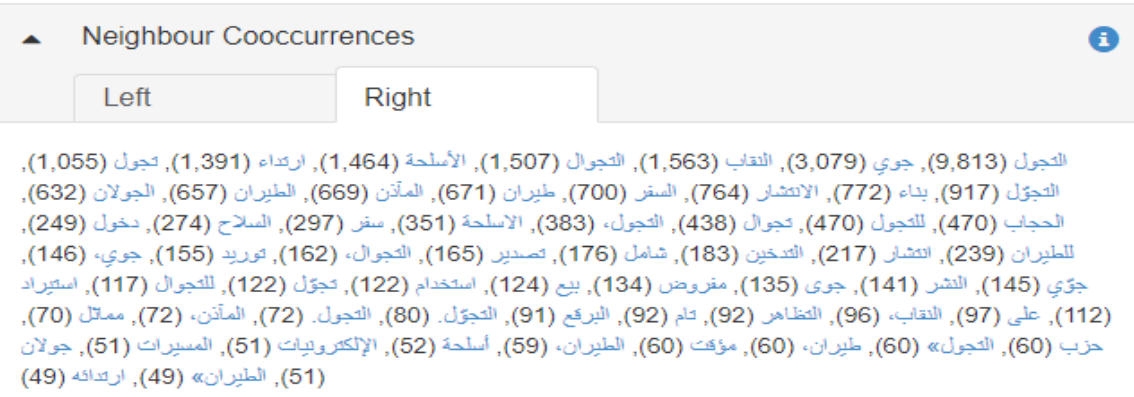

Figure 6 shows the words that could follow حظر which is on the right. The cooccurrences of words that are on the right and left حظر listed in Table 6

\begin{tabular}{ccc}
\hline Left & word & Right \\
\hline حظر & \\
\hline & حظر & \\
\hline
\end{tabular}




$$
\text { حظر استمرار }
$$

The table 6 shows that collocation with حظر was very much found in the text that contains information about the lockdown that become issues that arises from 2019 until now. Lexical collocation it has become a factor essential to trigger the increase of knowledge (aspect cognitive) for all the people to introspect themselves to this issue.

Tabel 7. Collocation Gramatical in Arabic

\begin{tabular}{|c|c|c|c|c|c|}
\hline No & Example & Mean & Wor & class category & \\
\hline 1 & منطقة حظر & 'lockdown area' & Noun & Noun & \\
\hline 2 & على حظر & 'in lockdown' & preposition & Noun & \\
\hline 3 & كان مقترحًا حظر & 'pupose for lockdown & conjunction & Verb & Noun \\
\hline 6 & وأن حظر & 'and if lockdown' & preposition & conjunction & Noun \\
\hline
\end{tabular}

A grammatical collocation is a phrase that consists of the word dominant (noun, adjective, and verb) and preposition/word function or form ${ }^{26}$ grammatical as infinitive verb and clause. Focused on the concept that research is finding some use collocation in a discourse presenting news about the coronavirus. Here's a variety of collocation identified as grammatical collocation.

\section{Data 2 على حظر}

Data 2 unit language of على حظر identified as collocation which has a structure syntax as follows: preposition + Noun. Collocation on Data على حظر consists of two

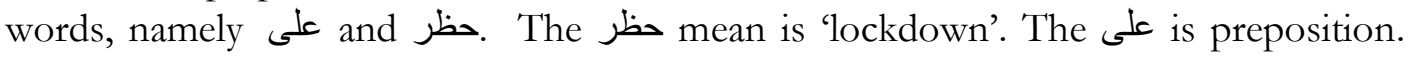
This word is used to mark the meaning of above, at, with. The حظر عظر categorized as nouns. Collocation types is found in the form of a phrase that serves as filler function statement in the clause, example: كتبت بالقلام 'I write with a pen.' Form على حظر and is an ecocentric phrase. In the phrase there is no element of the core and extra. The second element is the unity of the whole.

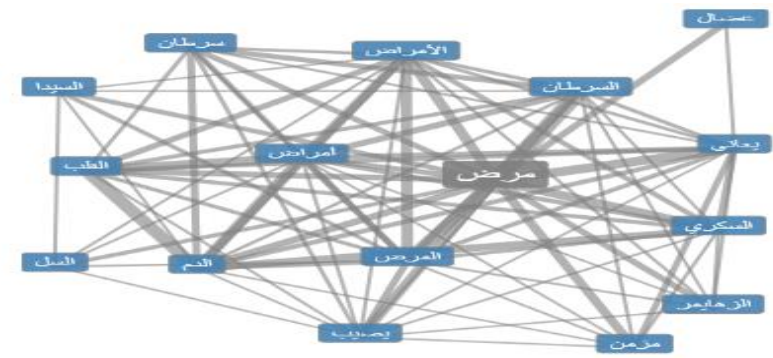

Source: https://corpora.uni-leipzig.de/

Examples of the use of the word مرض 'disease ' in sentence

${ }^{26}$ H. Men, Vocabulary Increase and Collocation Learning, 36. 


$$
\text { ا مرض فيروس كورونا (كوفيد-19). }
$$

ب ب بروسات كورونا فصيلة واسعة الانتشار معروفة بأهها تسبب أمراضاً تتراوح من نزلات البرد الشائعة إلى الاعتلالات الأشـد

وطأة مثل متلازمة الشرق الأوسط التنفسية (MERS) ومتلازمة الالتهاب الرئوي الحاد الوخيم (السارس).

Source: https://www.who.int/ar/news-room/q-a-detail/coronavirus-diseaseCovid-19

Coronavirus associated lexical collocation in Arabic at the مرض

Lexical collocation following is taken from some text news that into the data in the study of this, the results of observations can be seen in table 8 below this.

\begin{tabular}{|c|c|c|c|c|}
\hline $\mathrm{No}$ & Example & & egory & \\
\hline & Lexical collocation in Arabic & Word class & Word class & Word class \\
\hline 1 & بضيق التنفس الشديد & adverb & Noun & adjective \\
\hline 2 & مرض انفلونزا & adjective & Noun & \\
\hline 3 & يسبب فيروس كورونا & Noun & Noun & Noun \\
\hline 4 & السيطرة على كورونا & Noun & conjunction & Noun \\
\hline
\end{tabular}

In the Leipzig copus collocation are divided according to the location of the cooccurrences or the appearance of the accompanying word. There are two co-occurrences, are words that appear in the next word (left neighbor coocurences) and the next right (right coocurences). Occurrences co-occurrences of مرض listed in Table 9

\begin{tabular}{lll}
\hline Left & word & Right \\
\hline & مرض ملاج & \\
\hline & مرض & \\
\hline
\end{tabular}

The data listed in Table 9 shows that collocation that is associated with the epidemic very much found in the text that contains information about coronavirus disease into the issue that arise from 2019 until now. Lexical collocation has become a factor essential to trigger the increase of knowledge about this issue. Grammatical collocation Coronavirus associated grammatical collocation in مرض.

Table 10

\begin{tabular}{|c|c|c|c|c|c|}
\hline No & Example & \multicolumn{4}{|c|}{ Category } \\
\hline & Collocation in Arabic & Word class & Word class & Word class & Word class \\
\hline 1 & من أي مرض & Preposition & adverb & adjective & \\
\hline 2 & بالعاملين الصحيين & Conjunction & Noun & Noun & \\
\hline 3 & لمضياعفات مرض فيروس & Conjunction & Noun & adjective & Noun \\
\hline 4 & وكأنّ مرض & Conjunction & verb & adjective & \\
\hline
\end{tabular}




\section{Arabiyât Jurnal Pendidikan Bahasa Arab dan Kebahasaaraban, 8 (2), 2021}

A grammatical collocation is a phrase that consists of the word dominant (noun, adjective, and verb) a preposition/word of function or form grammatical like verb of infinitive and clause. This research found some use collocation in a discourse that contains news about the coronavirus. Here's sentences were identified as grammatical collocation. The grammatical collocation is as follows.

\section{Data 3 من أي مرض}

Arabic word chain of sidentified as collocation which has a structure syntax as follows: preposition + adverb+ adjective. Collocation at Data sن 3 من إي

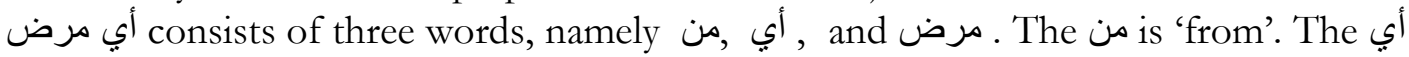
is adverb. This word is used to mark the meaning

categorized of adjective. Collocation types is found in the form of a phrase that serves as filler function statement in the a clause, an example of another: لقاح فيروس كورونا Vaccine coronavirus is mandatory.' Form ، لقاح فيروس كورونا إلزامي a nominal clause which has one subject function and one predicate function.

\section{Data 4 وكانّكن مرض}

Unit of languages وكأنّ مرض is identified as collocation which has a structure syntax as follows: conjunction + adjective. Collocation Data وكأن مرض مرض و 4 وكر consists of

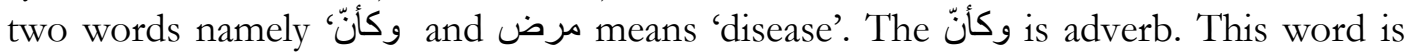
used to denote the meaning of 'as if'.

The مرض is categorized as an adjective. This type of collocation is found in the form of phrase that function as fillers for exocentric phrase functions. In the phrase there is no element of the core and extra. The second element is the unity of the whole. One element cannot replace another element.

Consider the example: السَّماءُ ثُمطرُ الآنَ في الخارج, 'Rained down on the outside'. Phrase الخار ج is a good exocentric phrase nor في الخارج is element of a unified whole.

\section{Indonesian Collocation}

The use of the word associated with the coronavirus began to be used as widely in the end 2019. In linguistic corpus, words that appear on the side right or left of the word is called collocation. Collocation or sanding kata occurs between the word with another word that side by side in a sentence. Research have resulted in two findings, namely 1) the category the category of collocation according to its kind, and 2) categories of collocation according to the meaning between an element and another element. In this case there are similarities associated or the possibility of their few words in a neighborhood that is equal in a sentence or discourse Halliday and Harsana explain that collocation is the associated remained word with another word that coexist in sentence. The collocation or sanding kata is associate particular in using choice 
words that tend to be used in side by side. ${ }^{27}$ The words that collocate in the findings of this study are words used in a domain of coronavirus disease.

Lexical collocation refers to phrase consists of a combination of a noun, adjective, verb, and adverb. Lexical collocation is the meaning of the word that is actually in accordance with the reference as a result of observation senses and apart from the element of grammatical. Lexical is the meaning in the dictionary. The lexical meaning is the meaning of the word is not influenced by other forms. The coronavirus in Indonesian, the form of the collocation can be seen in the form of a graph of corpus Leipzig on graph 4 as follows:

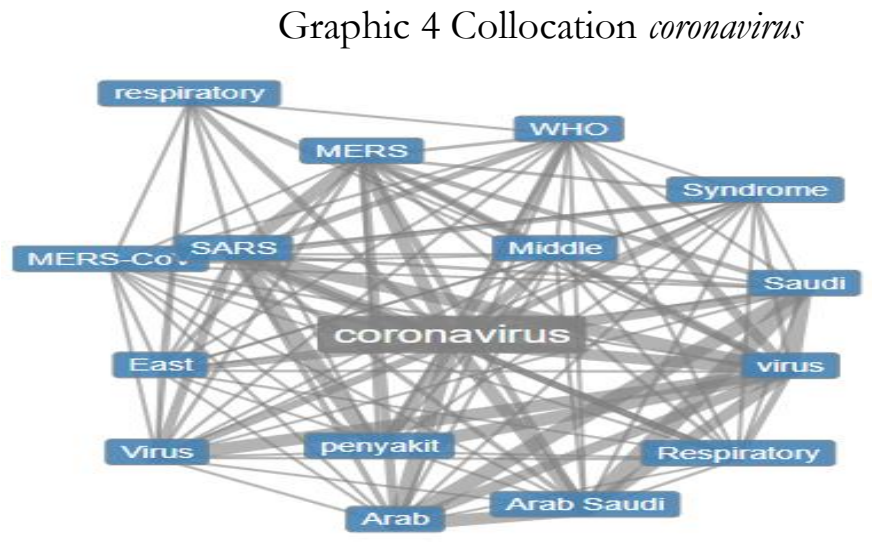

Source: https://corpora.uni-leipzig.de/

The unit of language in the form of coronavirus was identified as a compound word. The word is constructed by nouns and noun. This word is identified as a loanword from English. The collocation can be seen in table 11:

\begin{tabular}{llcc}
\hline No & Example & \multicolumn{2}{c}{ Composition } \\
\hline & Lexical collocation in Indonesian & Word class & Word class \\
\hline 1 & [penyakit coronavirus](coronavirus disease) & Noun & Noun \\
\hline 2 & [respiratory coronavirus] & Adjective & Noun \\
\hline 3 & [pasien coronavirus](coronavirus patient) & Noun & Noun \\
\hline
\end{tabular}

Lexical Collocation Analysis

This research found three types of lexical collocation with pattern: 1) Noun + Noun; 2) Adjective + Noun, 3) Verb + Noun. The analysis of each pattern is as follows:

${ }^{27}$ Cynthia Veronika, "The Structure of Collocation and Its Translation Structures in Subtitles of Kurzgesagt Youtube Channel”, Klausa, Vol. 4, No. 1, 2020, 2; See again Ni Luh Putu Setiarini and Mangatur Nababan, "The Patterns and Translation Techniques of English-Indonesian Verbal Node Collocations", Pertanika Journal of Social Science and Humanities, Vol. 27, No. 4, 2019, 4. 
Data 5 penyakit coronavirus/coronavirus disease

Collocation at the top has the form of a phrase the noun, in that phrase verb explains about verb. Collocation of penyakit coronavirus/ coronavirus disease has a structure (noun + noun) consisting of penyakit/ disease which is a noun and coronavirus is a modifier (additional meaning) and disease is head (core meaning), because the word of coronavirus serves to explain the word penyakit/disease.

\section{Data 6 respiratory coronavirus}

Collocation at the top has a form phrase adjective, in the phrase explain to adjective and verb. Collocation of respiratory coronavirus has the structure (adjective + noun) consists of respiratory which are adjectives and coronavirus which is a noun. Word of respiratory is modifier and coronavirus is head (meaning core).

In the corpus Leipzig collocation of coronavirus divided based on location of cooccurrences. There are two co-occurrences namely, left neighbor co-occurrences and right cooccurrences. The co-occurrences of coronavirus is listed Table 10

\begin{tabular}{ccc}
\hline Left & Word & Right \\
\hline pasien & coronavirus & \\
\hline & coronavirus & tersebut \\
\hline
\end{tabular}

\section{5 as follows:}

Word of wabah in Indonesian, can be seen at graph of Corpus Leipzig at graph Graphic 5. Collocation of wabah

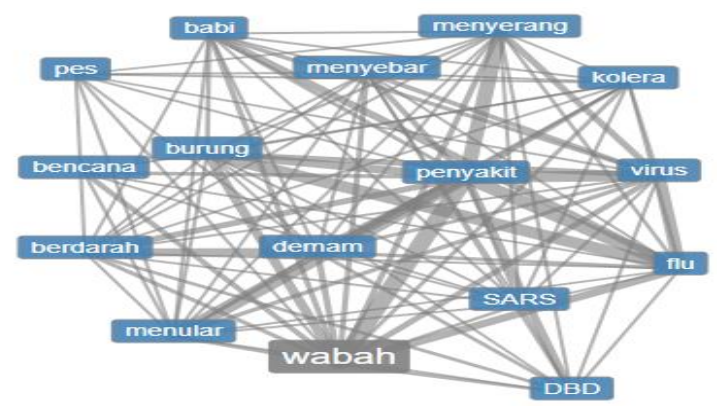

Source: https://corpora.uni-leipzig.de/

Table 11. Lexical Collocation in Indonesian Regarding Coronavirus

\begin{tabular}{llll}
\hline No & Example & \multicolumn{2}{c}{ Composition } \\
\hline & Lexical collocation in Indonesian & Word class & Word class \\
\hline 1 & [terjangkit wabab] & Verb & Noun \\
\hline 2 & [wabah virus] & Noun & Noun \\
\hline 3 & [terinfeksi wabah] & Verb & Noun \\
\hline 4 & [bencana wabab] & Noun & Noun \\
\hline
\end{tabular}


Ara6iyât Jurnal Pendidikan Bahasa Arab dan Kebahasaaraban, 8 (2), 2021

5 [wabah menular] Noun Verb

Lexical collocation in the sentence:

1 Misteri wabah coronavirus belum terpecabkan.

(The mystery of the coronavirus outbreak has not been solved.)

2 Corona merupakan penyakit yang sangat potensial untuk menimbulkan wabah menular.

(Corona is a disease that has the potential to cause infectious outbreaks.)

In the Leipzig corpus, collocation is divided based on the location of cooccurrences. There are two co-occurrences, left neighbor coocurences and right co-occurrences. The occurrence of coocurences of the wabah listed in Table 12

\begin{tabular}{lll}
\hline Left & Word & Right \\
\hline terkena & wabah & \\
\hline & wabah & Coronavirus \\
\hline
\end{tabular}

The data above shows that collocations associated with the wabah was found in many text that contains information about the disease coronavirus that emerged from 2019 until now. It has become a essential factor to trigger the increase of knowledge (cognitive aspect) for all the people.

\section{Grammatical Collocation}

A grammatical collocation is a phrase that consists of the word dominant (noun. adjective, and verb) and preposition's grammatical function as infinitive verb and clause. $^{28}$ This research found some uses of collocation in a discourse that contains about the coronavirus. The sentences identified as grammatical collocation can be seen bellow:

1 Gejala yang dirasakan Ali setelah sembuh dari coronavirus adalah kelelahan.

(Symptoms are felt Ali after recovering from a coronavirus is exhausted.)

2 Coronavirus baru datang dari India.

(New coronavirus coming from India.)

In sentences 1-2 contains grammatical collocation. The analysis of grammatical collocation namely:

Data 7 sembub dari coronavirus/ recovered from coronavirus

Data 7 shows sembuh dari coronavirus identified as collocation which has a structure syntax: Verb + preposition + Noun. Collocation of sembub dari coronavirus consists of three words, namely: sembuh, dari dan coronavirus. The word of sembub a

${ }^{28}$ H. Men, Vocabulary Increase and Collocation Learning, 36. 
category of verb. The word of dari, identified as a preposition. This word is used to denote the meaning of 'origin, stae, time.' The word of coronavirus is categorized as a noun. This type of collocation is found in the form of verbal clause, namely clause that indicate origin or state. The word coronavirus is an object (O) and sembub is predicate $(\mathrm{P})$. In Indonesian, clause verb followed by preposition forward had the marker as a function of grammatical. In the clause sembub akibat coronavirus, the word of dari function to connect the word of sembuh and coronavirus is the preposition due to meaning of origin or condition.'

Based on the results of the analysis it is found that the collocation coronavirus associated collocation has a pattern which varies depending on the context and concepts are presented. Pattern collocation related terms coronavirus in Indonesian in term of: 1) Aspect of lexical found as many as 223 collocation found three pattern of lexical collocations namely: i) 40 collocation pattern verb + noun; ii) 30 collocation pattern noun + noun; iii) 20 collocation pattern noun + verb; iv) 30 collocation pattern noun + adjective; v) 16 collocation pattern adjective + noun. This research found 178 data grammatical collocation with composition, as follows: i) 72 collocation structure: Verb + preposition + noun; ii) 42 collocation structure: verb + noun; iii) 34 collocation structure Adverb + noun + Adjective; iv) 46 collocation structure preposition + noun + noun; v) 22 collocation structure conjunction + Adjective + noun.

\section{Conclusion}

Based of analysis of collocation and linguistic corpus approach using software of corpora.uni-leipzig.de, section a) was found two types of lexical collocation and grammatical collocation. And next question research section b) pattern layout sequence of words forming the collocation associated with the term of pandemic Covid-19 in English is pattern that is much absorbed into the pattern Indonesian. That is the Indonesian get the collocation of new related term pandemic of the English. Pattern of collocation Arabic has a pattern of its own that different from the collocation of English and Indonesian, although so than 322 collocation of English there are 84 collocation absorb from English collocation. It is suggested that students or researchers do research based on linguistic corpus of taking an object across a language other than English, Arabic, and Indonesian in different context. Each unit of language which becomes the object can be analyzed on the level of syntaxes, semantic cognitive, social semiotic, functional linguistics system, dialectology, or sociolinguistics.]

\section{REFERENCES}

Aji, Pandu Rizki. "Kolokasi Dan Hiponim Sebagai Aspek Keutuhan Wacana Iklan Otomaotif Dalam Surat Kabar Suara Merdeka Periode Mei 2014 Dan Implikasinya Pada Pembelajaran Di SMA", Thesis, Universitas Muhammadiyah Purwokerto, 2015. 


\section{Arabiyât Jurnal Pendidikan Bahasa Arab dan Kebahasaaraban, 8 (2), 2021}

Alasmri, Ibrahim., and Haidee Kruger. "Conjunctive Markers in Translation from English to Arabic: A Corpus-Based Study", Routledge, Taylor and Francis Group, Vol. 26, No. 5, 2018.

Brierley, Claire., and Hanem El-Farahaty. "An Interdisciplinary Corpus-Based Analysis of the Translation of كر امة (Karāma, 'Dignity') and Its Collocates in ArabicEnglish Constitutions”, The Journal of Specialised Translation, Vol. 32, 2019.

Cantos-Gómez, Pascual., and Moisés Almela-Sánchez. Lexical Collocation Analysis Advances and Applications. Spain: Springer, 2018.

Creswell, J.W. Research Design Qualitative Quantiative and Mixed Methods Approaches Third Edition. Third Edition. California: SAGE Publication, Inc., 2009.

Gregorio-Godeoa, Eduardo de., and Silvia Molina. "Collocations and the Translation of News: An English_Spanish Electronic Dictionary of Multi-Word Combinations as a Translation Tool", Routledge, Taylor and Francis Group, Vol. 19, No. 2, 2011.

Hendra, Faisal., and Mujahidah Fharieza Rufaidah. "Compiling Vocabulary Lists for Corpusbased Arabic For Tourism Teaching”, Arabiyat, Vol. 8, No. 1, 2021.

Hizbullah, N., and Muchlis, M.M. "Projected Characteristics and Content of Arabic Corpus in Indonesia", Advances in Social Science, Education and Humanities Research, 2018.

Hizbullah, Nur., and Zakiyah Arifa. "Source-Based Arabic Language Learning: A Corpus Linguistic Approach", Humanities \& Social Sciences Reviews, Vol. 8, No. 3, 2020 .

Igaab, Zainab Kadim., and Hanan Abdulhasan. "Collocation in English and Arabic: A Contrastive Study", Canadian Center of Science and Education, Vol. 8, No. 4, 2018.

Ihalainen, Pasi., and Aleksi Sahala. Evolving Conceptualisations of Internationalism in the UK Parliament. In M. Fridlund, M. Oiva, \& P. Paju (Eds.), Digital Histories: Emergent Approaches within the New Digital History. Helsinki: Helsinki University Press, 2020.

Izwaini, Sattar. "Patterns of Lexical Collocations in Arabic", Researchgate, 2015.

Khan, Jahangeer., and Chengyu Liu. "The Impact of Colors on Human Memory in Learning English Collocations: Evidence from South Asian Tertiary ESL Students", Springer Open, Vol. 5, No. 17, 2020.

Lan, Ge., and Yachao Sun. "A Corpus-Based Investigation of Noun Phrase Complexity in the L2 Writings of a Firstyear Composition Course", Elsevier Ltd, Vol. 38, 2018.

Maher, Paschal., and Simon Milligan. "Teaching Master Thesis Writing to Engineers: Insights from Corpus and Genre Analysis of Introductions", Elsevier Inc, Vol. $55,2019$.

McEnery, T., and Hardie A. Corpus Linguistics: Method, Theory and Practice. Cambridge: Cambridge University Press, 2012.

Men, H. Vocabulary Increase and Collocation Learning. Shanghai: Springer, 2018. 


\section{Arabiyât Jurnal Pendidikan Bahasa Arab dan Kebahasaaraban, 8 (2), 2021}

Puspita, Dewi. "Etimologi Kosakata Melayu Nusantara Ranah Kekerabatan Kajian Semantik Historis", Thesis, Universitas Indonesia, 2020.

O'Keeffe, A., and McCarthy, M. The Routledge Handbook of Corpus Linguisfics. London: Routledge. London: Routledge, 2010.

Rafatbakhsh, Elaheh., and Alireza Ahmadi. "A Thematic Corpus-Based Study of Idioms in the Corpus of Contemporary American English", Springer Open, Vol. 4, No. 11, 2019.

Rahman, Abd. "Keberterimaan Istilah-Istilah Di Masa Pandemi Covid-19”, Bidar, Vol. 10, No. 2, 2020.

Riemer, Nick. Introducing Semantics. Cambridge: Cambridge University Press, 2010.

Seretan, Violeta. Bridging Collocational and Syntactic Analysis in Lexical Collocation Analysis. Spain: Springer, 2018.

Setiarini, Ni Luh Putu., and Mangatur Nababan. "The Patterns and Translation Techniques of English-Indonesian Verbal Node Collocations", Pertanika Journal of Social Science and Humanities, Vol. 27, No. 4, 2019.

Stubbs, M. Words and Phrases: Corpus Studies of Lexical Semantics. London: Blackwell Publishing, 2002.

Sugiyono. Metode Penelitian Kuantitatif, Kualitatif Dan R\&DD. Bandung: Alfabeta, 2014.

al-Thubaity, Abdulmohsen, and Ibtehal Baazeem. "A Collocation Extraction Tool and Two Language Resources for MSA”, Elsevier Ltd, Vol. 116, 2017.

Veronika, Cynthia. "The Structure of Collocation and Its Translation Structures in Subtitles of Kurzgesagt Youtube Channel”, Klausa, Vol. 4, No. 1, 2020.

Yule, George. The Study of Language. Cambridge: Cambridge University Press, 2013.

Zaabalawi, Rafe S., and Anthony M. Gould. "English Collocations: A Novel Approach to Teaching the Language's Last Bastion", Elsevier Ltd, Vol. 4, 2017. 